\title{
PENGARUH PENDIDIKAN KESEHATAN TERHADAP PERILAKU CUCI TANGAN PAKAI SABUN DENGAN AIR MENGALIR ANAK SD DI SEKOLAH DASAR NEGERI 157019 PINANGSORI 12 KABUPATEN TAPANULI TENGAH TAHUN 2018
}

\section{RUMIRIS SIMATUPANG ${ }^{1}$, MEIYATI SIMATUPANG²}

\author{
1,2 STIKes NAULI HUSADA SIBOLGA \\ Jln Kader Manik No 02 Kelurahan Aek Muara Pinang Sibolga Selatan \\ Email : rumirissimatupang2@gmail.com \\ DOI : https://doi.org/10.35451/jkf.v2i1.295
}

\begin{abstract}
Clean and Healthy Behavior (PHBS) is a set of behaviors that are practiced on the basis of awareness as a learning outcome, which makes a person, family, group and community able to help themselves (independent) in the health sector and play an active role in realizing public health. Clean and healthy life behavior is the second biggest factor after environmental factors that have an impact on the health of individuals, groups or communities. The purpose of this study was to determine the effect of health education on the behavior of washing hands with soap with running water in elementary school children in the 157019 Pinangsori Public Elementary School 12 Middle Tapanuli Regency 2018. This study used a Quasi Experimental research method using one group pretest-posttest design. The sample in this study was elementary school students grade IV at SDN Pinang Sori 12. Sampling used a total sampling technique with a number of respondents as many as 56 people. The results of the study $t$ value of the variable knowledge was $-9,151$ with a $p$ value of 0,000 $<0.05$ while the $t$ value for the attitude variable is $-15,394$ with a $p$ value of $0,000<0.05$ and the calculated value for the action variable is $-12,699 p$ value of $0,000<0.05$ using the paired t-test static test then, it is concluded that there is an influence PHBS counseling about washing hands on knowledge and attitudes and actions about washing hands in elementary school class IV Pinang Sori 12.
\end{abstract}

Keywords: Health Education, Knowledge, Attitudes, Actions

\section{PENDAhUluan}

Perilaku Hidup Bersih dan sehat adalah keseluruhan tindakan secara sadar yang merupakan hasil pembelajaran, yang menjadikan seseorang, keluarga, kelompok dan masyarakat mampu secara mandiri dalam bidang kesehatan serta turut berpartisipasi dalam kegiatan kesehatan masyarakat (Kemenkes RI, 2014).

Perilaku Sehat yaitu mencuci tangan pakai sabun dengan air mengalir merupakan cerminan PHBS, hal ini menjadi perhatian dunia karena masalah kurangnya tindakan perilaku mencuci tangan terjadi di negara berkembang dan juga di negara maju. 
Fokus mencuci tangan pakai sabun dengan air mengalir ini adalah Anak sekolah, yang mana anak sekolah dasar diharapkan dapat membawa perubahan pada seluruh komponen keluarga, rumah dan masyarakat dalam melaksanakan komitmen untuk perubahan yang lebih baik dalam berperilaku sehat melalui kegiatan mencuci tangan pakai sabun dengan air mengalir (Depkes, 2007).

Sekolah merupakan tombak perpanjangan tangan keluarga dalam meletakkan dasar pendidikan perilaku untuk anak termasuk perilaku kesehatan. Dilihat dari rata rata jumlah populasi anak sekolah dalam satu komunitas cukup besar yaitu antara $20 \%-30 \%$, maka dari itu promosi atau pendidikan kesehatan di sekolah sangat baik untuk dilakukan. (Notoatmodjo, 2010).

Terjadinya penyakit pada anak usia sekolah ternyata ada hubungannya terhadap perilaku hidup bersih dan sehat. Oleh karena itu, PHBS merupakan kebutuhan mutlak yang dapat dilakukan melalui pendidikan kesehatan itu sendiri. Penerapan perilaku hidup bersih dan sehat disekolah merupakan upaya yang dilakukan untuk memberdayakan siswa, agar mengetahui dan dapat mengaplikasikan perilaku hidup bersih dan sehat serta ikut menciptakan kondisi sekolah sehat (Proverawati, 2012).

Berdasarkan data dari kemenkes RI tahun 2017, sebanyak 1,7 juta anak meninggal karena diare setiap tahunnya, mencuci tangan dengan air hanya dapat membunuh kuman sebanyak 10 persen, namun dengan menggunakan sabun dapat membunuh kuman sampai 80 persen. Data tentang PHBS penduduk secara umum diketahui bahwa hanya sebanyak $47 \%$ masyarakat Indonesia yang melakukan praktek cuci tangan pakai sabun dengan benar.

Menurut penelitian Koem (2015) diperoleh hasil bahwa pengetahuan mempengaruhi perilaku PHBS pada anak Sekolah yaitu sebesar 23 responden $(45,1 \%)$ yang berperilaku tidak baik dengan pengetahuan yang tidak baik.

Salah satu upaya pemberian pendidikan kesehatan disekolah adalah melalui promosi kesehatan. Pendidikan kesehatan dapat dilaksanakan dengan menggunakan media yang disesuaikan dengan sasaran. Cara efektif dalam pendekatan kelompok adalah dengan metode diskusi dan ceramah. (Notoatmodjo,2007).

\section{METODE PENELITIAN}

Penelitian yang digunakan adalah penelitian quasi experimental dimana penelitian menguji coba suatu intervensi pada sekelompok subjek tanpa menggunakan kelompok Kontrol sebagai pembanding menggunakan rancangan penelitian one group pretestpostest design untuk mengetahui pengaruh pemberian Pendidikan Kesehatan tentang PHBS terhadap Perilaku PHBS pada siswa Sekolah Dasar kelas IV. Penelitian ini dilaksanakan di SDN. 157019 Pinangsori di mulai dari bulan April Sampai Agustus 2018.

Populasi dalam penelitian ini adalah seluruh Siswa Kelas IV SDN. 157019 Pinangsori 12 Kecamatan Pinang sori Kabupaten Tapanuli Tengah sebanyak 56 orang. Sampel dalam penelitian menggunakan teknik pengambilan sampel secara total sampling dimana semua populasi dijadikan sampel yaitu sebanyak 56 orang. Variabel independen penelitian ini adalah Pendidikan Kesehatan dan Variabel dependennya Perilaku PHBS Siswa SDN. 
157019 kelas IV Pinangsori 12. Analisis data dilakukan dengan pengujian statistik yaitu uji paired t-test untuk melihat pengaruh Perilaku anak tentang PHBS sebelum dan sesudah perlakuan, menggunakan individu yang sama. Dalam penelitian ini digunakan uji kolmogorov-smirnov dengan taraf signifikan $a=0,05$.

\section{HASIL PENELITIAN}

Tabel 4.2. Distribusi Frekuensi Pre Test Pengetahuan mencuci tangan pakai sabun dengan air mengalir.

\begin{tabular}{lcc}
$\begin{array}{l}\text { Pengetahuan } \\
\text { Pre Test }\end{array}$ & Frekuensi & Persentase \\
\hline Cukup & 46 & 82,1 \\
Kurang & 10 & 17,9 \\
\hline
\end{tabular}

Berdasarkan hasil pre test pada penelitian ini menunjukkan bahwa mayoritas responden memiliki pengetahuan Cukup sebanyak 46 orang $(82,1 \%)$

Tabel 4.3. Distribusi Frekuensi Post Test Pengetahuan Mencuci Tangan pakai sabun dengan air mengalir.

\begin{tabular}{lcc}
\hline $\begin{array}{l}\text { Pengetahuan } \\
\text { Post Test }\end{array}$ & Frekuensi & Persentase \\
\hline Baik & 39 & 69,6 \\
Cukup & 15 & 26,8 \\
Kurang & 2 & 3,6 \\
\hline
\end{tabular}

Berdasarkan hasil penelitian bahwa setelah diberikan Pendidikan Kesehatan mencuci tangan pakai sabun dengan air mengalir mayoritas pengetahuan responden meningkat menjadi baik sebanyak 39 orang $(69,6 \%)$.

Tabel 4.4. Distribusi Frekuensi Pre Test Sikap tentang Mencuci Tangan Siswa Kelas IV di SDN Pinang sori 12 tahun 2018

\begin{tabular}{lll}
\hline Sikap & Frekuensi & Persentase \\
Pre test & & \\
\hline
\end{tabular}

\begin{tabular}{lll}
\hline Positif & 19 & 33,9 \\
Negatif & 37 & 66,1 \\
\hline
\end{tabular}

Berdasarkan hasil penelitian pretest pendidikan kesehatan mencuci tangan pakai sabun dengan air mengalir pada siswa menunjukkan bahwa mayoritas sikap responden negatif sebanyak 37 orang $(66.1 \%)$.

Tabel 4.5. Distribusi Frekuensi Post Test Sikap Mencuci Tangan pakai sabun dengan air mengalir Siswa Kelas IV di SDN Pinang sori 12 tahun 2018

\begin{tabular}{lcc}
\hline $\begin{array}{l}\text { Sikap } \\
\text { Post Test }\end{array}$ & Frekuensi & Persentase \\
\hline Positif & 51 & 91,1 \\
Negatif & 5 & 8,9 \\
\hline
\end{tabular}

Hasil penelitian diatas menunjukkan terjadi peningkatan sikap responden sesudah mendapat Pendidikan Kesehatan tentang mencuci tangan pakai sabun dengan air mengalir dari sikap negatif menjadi sikap positif.

Tabel 4.6. Distribusi Frekuensi Pre Test Tindakan tentang Mencuci Tangan Siswa Kelas IV di SDN Pinang sori 12 tahun 2018

\begin{tabular}{lcc}
\hline $\begin{array}{l}\text { Tindakan } \\
\text { Test }\end{array}$ & Frekuensi & Persentase \\
\hline $\begin{array}{l}\text { Diberikan } \\
\text { Tidak }\end{array}$ & 8 & 14,3 \\
Diberikan & 48 & 85,7 \\
\hline
\end{tabular}

Hasil penelitian menunjukkan sebelum diberikan pendidikan kesehatan mayoritas responden tidak mencuci tangan pakai sabun dengan air mengalir sebanyak $85,7 \%$.

Tabel 4.7. Distribusi Frekuensi tindakan Post Test pendidikan kesehatan Mencuci Tangan pakai sabun dengan air mengalir Siswa Kelas IV di SDN Pinang sori 12 tahun 2018 
Jumal Keperawatan dan Fisioterapi (JKF), e-ISSN 2655-0830

Vol. 2 No.1 Edisi Mei-Oktober 2019

Received: 09 Oktober 2019 :: Accepted: 15 Oktober 2019:: Published: 31 Oktober 2019

\begin{tabular}{lcc}
\hline $\begin{array}{l}\text { Tindakan } \\
\text { Post Test }\end{array}$ & Frekuensi & Persentase \\
\hline Diberikan & 51 & 91,1 \\
Tidak & 5 & 8,9 \\
Diberikan & & \\
\hline
\end{tabular}

Hasil penelitian menunjukkan bahwa terjadi peningkatan tindakan mencuci tangan pakai sabun dengan air mengalir setelah diberikan Pendidikan Kesehatan.

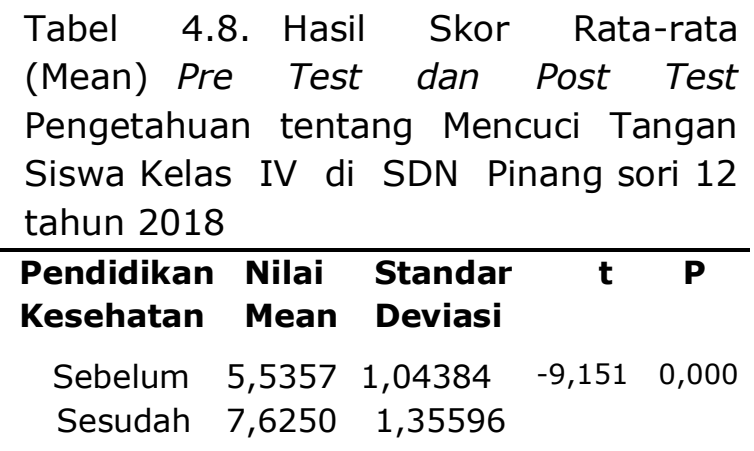

Berdasarkan hasil analisis dengan paired t-test pada tabel 4.8 terjadi peningkatan nilai rata- rata (Mean) pengetahuan sebesar 2,09 sebelum dan sesudah diberikan penkes dengan $t$ hitung adalah $-9,151$ (Pvalue $=0,000)$

Tabel 4.9. Distribusi Hasil Skor Ratarata (Mean) Pre Test dan Post Test Sikap tentang Mencuci Tangan Siswa Kelas IV di SDN Pinang sori 12 tahun 2018

\begin{tabular}{ccccc}
\hline $\begin{array}{c}\text { Pendidikan } \\
\text { Kesehatan }\end{array}$ & $\begin{array}{l}\text { Nilai } \\
\text { Mean }\end{array}$ & $\begin{array}{l}\text { Standar } \\
\text { Deviasi }\end{array}$ & t & P \\
Sebelum & 5,107 & 1,1229 & $-12,699$ & 0,000 \\
Sesudah & 7,500 & 1,0954 & & \\
\hline
\end{tabular}

Berdasarkan hasil analisis tabel 4.9 dengan paired $t$-test dari nilai rata-rata sikap responden sebelum dan sesudah diberikan Pendidikan Kesehatan terjadi peningkatan sebesar 2,393 dengan standar deviasi sebelum diberikan penkes sebesar 1,122 dan sesudah diberikan Pendidikan Kesehatan sebesar 1,095 dengan $t$ hitung adalah $-12,699$ (pvalue $=0,000$ ). Maka dapat disimpulkan bahwa ada pengaruh pemberian Pendidikan Kesehatan mencuci tangan pakai sabun dengan air mengalir terhadap sikap siswa Kelas IV SDN Pinang Sori 12.

Tabel 4.10. Distribusi Hasil Skor Ratarata (Mean) Pre Test dan Post Test Tindakan Mencuci Tangan pakai sabun dengan air mengalir Siswa Kelas IV SDN Pinang sori 12

\begin{tabular}{lllll}
\hline PenKes & $\begin{array}{l}\text { Nilai } \\
\text { Mean }\end{array}$ & $\begin{array}{l}\text { StandaD } \\
\text { eviasi }\end{array}$ & t & P \\
Sebelum & 4,4286 & 1,125 & $-15,39$ & 0,000 \\
Sesudah & 7,3750 & 1,071 & & \\
\hline
\end{tabular}

Berdasarkan hasil analisis paired t-test pada tabel 4.10 diperoleh hasil bahwa nilai rata-rata tindakan responden meningkat sebelum dan sesudah diberikan penkes sebesar 2,947 dengan standar deviasi sebelum diberikan penkes sebesar 1,125 dan standar deviasi sesudah diberikan pendidikan kesehatan sebesar 1,071 dan t-hitung $-15,394 \quad$ (pvalue $=0,000$ ). terjadi peningkatan nilai mean pada tindakan mencuci tangan sesudah diberikan Pendidikan Kesehatan, sehingga dapat disimpulkan bahwa ada pengaruh pemberian Pendidikan Kesehatan mencuci tangan pakai sabun dengan air mengalir terhadap perilaku siswa SD kelas IV pinang sori 12.

\section{PEMBAHASAN}

Hasil ini menunjukkan rata-rata pengetahuan responden meningkat menjadi pengetahuan baik setelah diberikan pendidikan Kesehatan. Dalam penelitian ini peneliti mencoba mengukur tingkat pengetahuan responden, yang dapat dilakukan dengan kuesioner tentang mencuci tangan. Seseorang yang mempunyai sumber informasi yang lebih banyak 
Received: 09 Oktober 2019 :: Accepted: 15 Oktober 2019:: Published: 31 Oktober 2019

akan banyak akal mempunyai pengetahuan lebih luas.

Peningkatan sikap yang positif disebabkan karena siswa mau memperhatikan pesan yang disampaikan melalui Pendidikan Kesehatan mencuci tangan pakai sabun dengan air mengalir yang merupakan program pendidikan kesehatan dari Usaha Kesehatan Sekolah. UKS di SDN Pinang sori 12 belum berjalan secara optimal, padahal UKS merupakan elemen kunci untuk meneruskan informasi-informasi kesehatan dari peer teaching ke anak usia sekolah dasar, sehingga perlu upaya pendidikan kesehatan berkenlanjutan untuk meningkatkan pengetahuan mencuci tangan pakai sabun denganair mengalir.

Pendidikan Kesehatan yang diberika nkepada responden diharapkan dapat meningkatkan kemauan responden untuk bertindak. Sikap bukan merupakan aktifitas tetapi merupakan predisposisi tindakan suatu perilaku. Pemberian Pendidikan Kesehatan mencuci tangan pakai sabun dengan air mengalir merupakan sesuatu yang memiliki makna dan pengaruh positif kepada responden.

Pendidikan kesehatan tentang perilaku hidup bersih dan sehat mengenai mencuci tangan pakai sabun memberikan perubahan positif terhadap perilaku siswa karena dengan pendidikan kesehatan melalui media leaflet dapat membantu siswa lebih memahami materi yang diberikan, para siswa akan lebih konsentrasi pada pemahaman sendiri karena melalui pendidikan kesehatan siswa mendengar dan melihat materi yang disampaikan. Selain itu anak sekolah dasar daya pikirnya sudah merujuk kepada hal hal yang bersifat konkrit dan rasional. Menurut piaget, masa tersebut dinamakan sebagai masa operasi konkrit dimana berakhirnya masa berpikir khayal dan mulai berfikir nyata.
Hal ini dibuktikan dengan perilaku PHBS mencuci tangan pakai sabun siswa menjadi lebih baik setelah mendapatkan pendidikan kesehatan dengan media leaflet dibandingkan dengan sebelum diberikan pendidikan kesehatan, untuk itu diharapkan siswa dapat mempertahankan dan meningkatkan perilaku cuci tangan pakai sabun dengan air mengalir.

Menurut atikah \& eni (2012), bahwa mencuci tangan pakai sabun dengan air mengalir merupakan perilaku yang dipraktikkan atas dasar kesadaran yang merupakan hasil dari pembelajaran yang dapat menjadikan anak-anak menolong dirinya sendiri untuk mencapai kesehatan ikut berperan dalam mewujudkan kesehatan. Perilaku hidup bersih dan sehat sangatlah dibutuhkan dimulai sedini mungkin. Banyak sekali dampak yang akan terjadi jika tidak berperilaku bersih dan sehat bagi para siswa, antara lain sakit diare, cacingan sehingga prestasi belajar menurun.

Hasil uji statistik bivariat dengan menggunakan paired $t$-test pada tabel 4.10 diperoleh nilai rata-rata tindakan responden sebelum diberikan Penkes mencuci tangan pakai sabun dengan air mengalir sebesar 4,428 dengan standar deviasi sebesar 1,125 dan sesudah Pendidikan Kesehatan sebesar nilai rata rata (mean) sebesar 7,375 dengan standar deviasi seesar 1,071 dan thitung $-15,394$ ( $p$ value $=0,000$ ). terjadi peningkatan nilai mean pada tindakan mencuci tangan sesudah diberikan Pendidikan Kesehatan,

Pendidikan mencuci tangan pakai sabun dengan air mengalir melalui teknik demonstrasi memiliki pengaruh besar terhadap perilaku, hal ini terjadi karena menurut teori pembelajaran Magnesen mengatakan bahwa anak mampu memahami 50\% dari apa yang 
mereka lihat dan mereka dengar, 70\% dari apa yang mereka katakan sendiri, dan $90 \%$ dari apa yang mereka katakan dan lakukan sendiri (CochranSmithn dan Zeichner, 2010).

\section{KESIMPULAN}

Berdasarkan rumusan hipotesis dinyatakan bahwa:

1. Terdapat pengaruh pemberian Pendidikan Kesehatan mencuci tangan pakai sabun dengan air mengalir terhadap pengetahuan

\section{DAFTAR PUSTAKA}

Anisa, D.N. 2012.Perilaku Pendidikan Kesehatan Terhadap Perilaku Cuci Tangan Pakai Sabun Pada Anak Usia Sekolah di SD 2 Jambinan Banguntapan Bantul. Skripsi tidak dipublikasikan STIKES 'Aisyiyah Yogyakarta.

Arikunto, Suharsimi. 2006. Prosedur Penelitian Suatu Pendekatan Praktik. Jakarta: Rineka Cipta.

Depkes RI. 2005. Perilaku Hidup Bersih dan Sehat. Bakti Husada. Jakarta.

Depkes RI. 2005. Profil Kesehatan Indonesia Tahun 2011.

Depkes RI. Laporan Hasil Riset Kesehatan Dasar Indonesia tahun 2007. Jakarta

Badan Penelitian dan Pengembangan Kesehatan Depkes RI; 2007

Dermawan, Deden. 2012. Buku Ajar Keperawatan Komunitas Edisi 1. Yogyakarta : Gosyen Publishing

Gunarsa, (2006). Psikologi Perkembangan Anak dan Remaja. Cetakan 12. Jakarta : Gunung Mulia.

Kementerian Kesehatan Republik Indonesia. 2014. Profil Kesehatan siswa SD kelas IV Pinang sori 12 tahun 2018

2. Terdapat pengaruh pemberian Pendidikan Kesehatan mencuci tangan pakai sabun dengan air mengalir terhadap Sikap siswa SD kelas IV Pinang sori 12 tahun 2018

3. Terdapat pengaruh pemberian Pendidikan Kesehatan mencuci tangan pakai sabun dengan air mengalir terhadap tindakan siswa SD kelas IV Pinang sori 12 tahun 2018.

Indonesia Tahun 2013. Jakarta : Depkes.

Kementerian Kesehatan Republik Indonesia. 2011. Profil Kesehatan Indonesia Tahun 2010. Jakarta : Depkes.

Koem, Zitty A.R.2015. Hubungan antara pengetahuan dan sikap dengan perilaku hidup bersih dan sehat ( PHBS) pada pelajar di SD Inpres sukur kecamatan air madidi Kabupaten Minahasa Utara. Jurnal Ilmiah Farmasi Vol.4.no.4 ISSN 2302-2493

Kriswanto. E.S, (2012). Konsep proses dan Aplikasi dalam Pendidikan Kesehatan. Yogyakarta: Fakultas Ilmu Keolahragaan Universitas Negeri Yogyakarta

Maulana. HDJ. 2009. Promosi Kesehatan. Jakarta.EGC

Mu'rifah. (2004). Pendidikan Kesehatan. Jakarta: Pusat Penerbitan Universitas Terbuka Departemen Pendidikan Nasional

Notoatmodjo, Soekidjo. 2003 Ilmu Kesehatan Masyarakat ( Prinsip Prinsip Dasar). Jakarta: PT. Rineka Cipta.

Notoatmodjo, Soekidjo. 2007. Pendidikan dan Promosi Kesehatan. Jakarta: Rineka Cipta. 2010. Promosi 
Kesehatan Teori dan Aplikasinya. Jakarta: Rineka Cipta.

2012. Promosi

Kesehatan diSekolah. Jakarta; Rineka Cipta

---------------, 2014, Ilmu Perilaku Kesehatan, Jakarta: PT Rineka Cipta.

Potter dan Perry., 2005.Buku Ajar Fundamental Keperawatan : Konsep, Proses, dan Praktik Edisi 4 Volume 1, EGC, Jakarta.

Proverawati, A \& Eni R. 2012. Perilaku Hidup Bersih Dan Sehat (PHBS). Yogyakarta: Nuha Medika.

Sulastri, Ketut et al.2014. Hubungan Tingkat Pengetahuan dengan perilaku anak sekolah tentang hidup bersih dan sehat di sekolah dasar Negeri Wilayah Puskesmas salemadeg Timur II. Jurnal kesehatan Lingkungan Vol.4 No.1 Mei 2014; 99-106

Suryabrata,Sumadi. 2010.Psikologi Pendidikan. Raja Grafindo Persada: Bandung

Unicef. 2012. Pada hari Cuci Tangan Sedunia, UNICEF mengatakan: ini tidak rumit,tapi penting, http/www.unicef.org/indonesia/id /media 19772.html diakses pada 09 Februari 2013 